\title{
ASSESSMENT OF THE INFLUENCE OF LARGE ROUGHNESS ELEMENTS ON HYDRAULIC CONDITIONS OF WATER FLOW IN THE BĘDKÓWKA STREAM CHANNEL
}

\author{
Bogusław Michalec ${ }^{\bowtie}$, Monika Zwolenik \\ Department of Hydraulic Engineering and Geotechnics, University of Agriculture in Kraków, Al. Mickiewicza 24/28, 30-059 Kraków
}

\begin{abstract}
Aim of the study

The paper presents the results of studies carried out in the channel of the Będkówka stream that were to assess the influence of large roughness elements on the change of value of roughness and resistance coefficients.

Material and methods

In a stream section selected for the study nine measurement cross-sections were designated and in three of them large roughness elements were present. Dimensionless resistance coefficient $(\lambda)$ was calculated from the Colebrook-White equation.
\end{abstract}

\section{Results and conclusions}

It was stated that in the cross-sections, where large roughness elements were present, the values of water flow velocity, resistance coefficients, as well as roughness coefficients are higher than in other cross-sections. Also, the sectional cover coefficient $(\omega)$ and the degree of change of roughness coefficient $\Delta n$ were calculated. Regressive dependency $\Delta n=f(\omega)$ of assessment of the hydraulic conditions of water flow change, which is expressed with the change of roughness coefficient was defined.

Keywords: large roughness elements, dimensionless resistance coefficient, roughness coefficient

\section{INTRODUCTION}

Large roughness elements are defined as elements that are distinguished by a several times larger diameter in comparison to diameter of other elements forming a sandbank; they decide about variable roughness of a stream bed section, and it is their shadow where finer elements assemble (Korpal et al., 2008). Large roughness element that can be found in a stream bed may be of natural origin or may be introduced into a stream bed in connection with regulation works aimed at improving ecological conditions. Introduction of large roughness elements into stream beds is realised ever more often within so called close-to-nature regulations as a means of recreating stream bed sandbanks in regulated mountain stream beds (Radecki-Pawlik, 2014). The elements, as stream bed microforms, are to initiate the creation of stream bed gravel forms in order to recreate biological life in their region (Korpak et al., 2008). These elements constitute a stream bed structure of increased roughness. Strużyński et al. (2013) claim that stream and mountain river beds are subject to changes of granulometric composition and of river load movement conditions when an increased flow roughness is observed. Fine material gathers between large roughness elements, what provides good habitat conditions for living organisms

凶e-mail:rmmichbo@cyf-kr.edu.pl 
(Bacuła et al., 2013). They constitute habitat elements especially for invertebrates, provide shadow which decreases water temperature differences during the day, provide shelter for fish.

Large roughness elements are also used to build fish passages. They may be embedded in concrete of bottom of slot fish passes or constitute elements of so called close-to-nature fish passes, i.e. bottom ramps, bottom slopes and bypass channels for fish (FAO/ DFWK 2002).

Introduction of large roughness element into a stream contributes to covering a part of stream's cross-section and to a change of hydraulic conditions of the water flow caused by the greater water flow resistance (Michalec and Strutyński, 2010). It is reflected in increased values of dimensionless resistance coefficient and roughness coefficient in relation to these values in the same section when elements are not present. Defining a degree of change of these parameters, which results from the introduction of large roughness elements may prove helpful in designing watercourse routes, channels that act as ecological passes for fish in the area of waterworks, or during engineering works related to improving watercourse ecological state.

According to Nitsche et al. (2011) a total stream water flow resistance is usually defined with parameters of roughness and friction. In literature, the total resistance is often described as a sum of element re- sistance and form resistance (incl. Carson and Griffiths, 1987; Gomez and Church, 1989; Millar and Quick, 1994; Millar, 1999). According to Nitsche et al. (2011), however, water flow resistance consists of two main components, i.e. the primary resistance caused by water bed wall surface resistance, which can be defined as a total resistance for deep flows, and of the secondary resistance caused by high roughness of large roughness elements. This attitude is also presented in "Fish passes - Design, dimensions and monitoring" paper (FAO/DFWK 2002), where it is suggested to calculate the river bed resistance coefficient with known bottom material from the Colebrook-White equation that is marked in the cited work with (4.2) symbol. When calculating the mean water flow velocity with the Darcy-Weisbach equation, the influence of roughness dominated by boulders resistance is taken into account (FAO/DFWK 2002).

The paper presents results of studies carried out to assess the influence of large roughness elements on the change of hydraulic parameters of water flow. The aim of the studies was to determine the degree of changes of dimensionless resistance coefficients and of river bed roughness coefficients in designated cross-sections of the stream, which came into being as a result of large roughness elements influence. The studies were carried out in the Będkówka stream, a left-bank tributary of the Rudawa river.

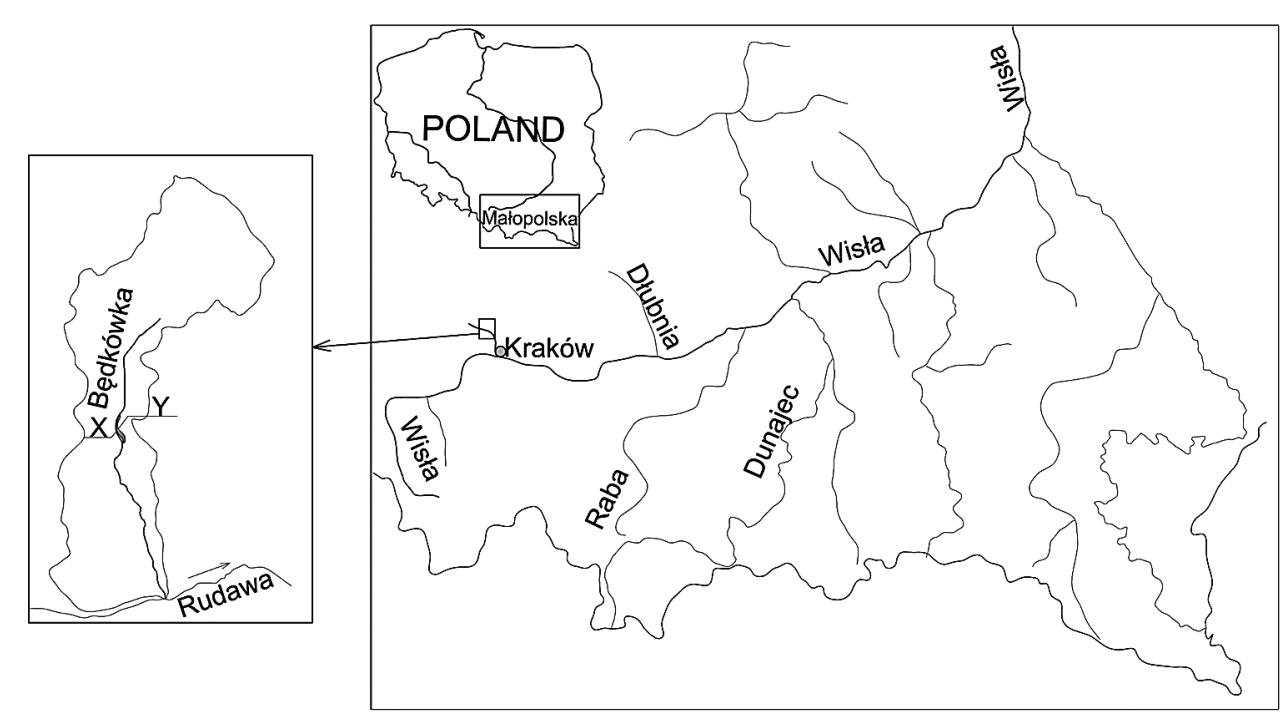

Fig. 1. Catchment of the Będkówka stream; 1 - research section, Y - fish ponds of the Będkowska Dolina fish farm 


\section{MATERIALAND METHODS}

The studies were carried out within a 37-metre long section of the Będkówka stream, in the town of Rudawa near the city of Kraków. The Będkówka stream is a left-bank tributary of the Rudawa river, which is a left-bank tributary of the Vistula river. Catchment area of the Będkówka stream covers $24.9 \mathrm{~km}^{2}$, and the stream's total length is $8.3 \mathrm{~km}$. The stream is not under any hydrometeorological observations.

Within the chosen research section (see: Fig. 2), where four large roughness elements were present, nine cross-sections were designated: the first one was located on the 4+200 kilometre, and the last one on the 4+227 kilometre of the Będkówka stream. Three cross-sections were selected in the elements' axis in two cross-sections, i.e. in the V and the VIII, one eleme0nt was present, while in cross-section II there were 2 elements (see: Fig. 2). Cross-sections were designated before and after each element in such a manner that they were outside of the zone of the element's influence on water flow.

Two series of measurements were performed at different water flow rates - the first one on 18th Septem- ber 2018 (see: Fig. 3) and the second one on 29th October 2018. In order to define geometrical parameters of cross-sections, as well as dimensions of elements, geodetic measurements with the AT-G7 level were performed. Bottom drop and water table drop were determined on the grounds of geodetic measurements on the $37 \mathrm{~m}$ mark, i.e. with extreme measurement points in the distance of $5 \mathrm{~m}$ below cross-section I and over cross-section IX. The bottom drop was determined on the grounds of geodetic measurements of the cross-sections, with the lowest elevation of the bottom of a given cross-section used to calculate it. In order to determine granulometric composition of the stream's bottom material, a sample of the load was obtained from the site. Only one $13.1 \mathrm{~kg}$ sample was obtained because of difficulties in obtaining more samples. The difficulties arose from the fact that only small amount of low depth river load padding out the outcrop was available. As river load composition was of relatively larger diameter it turned out that obtaining several representative river load samples from different sections was impossible. In order to provide representative results of the granulometric marking river load samples will be obtained during upcoming planned measurement series.

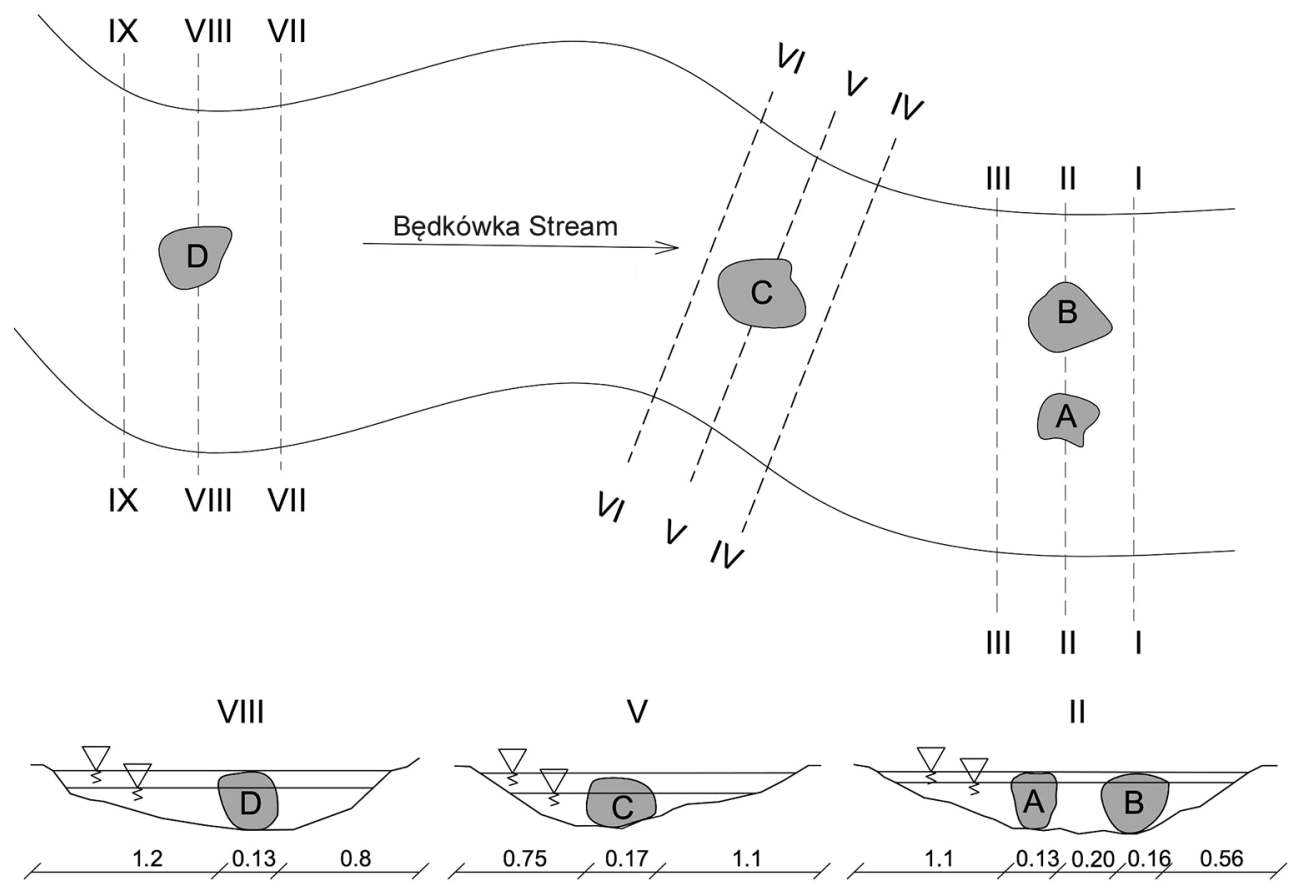

Fig. 2. Location of the measurement stations and cross-sections with large roughness elements 


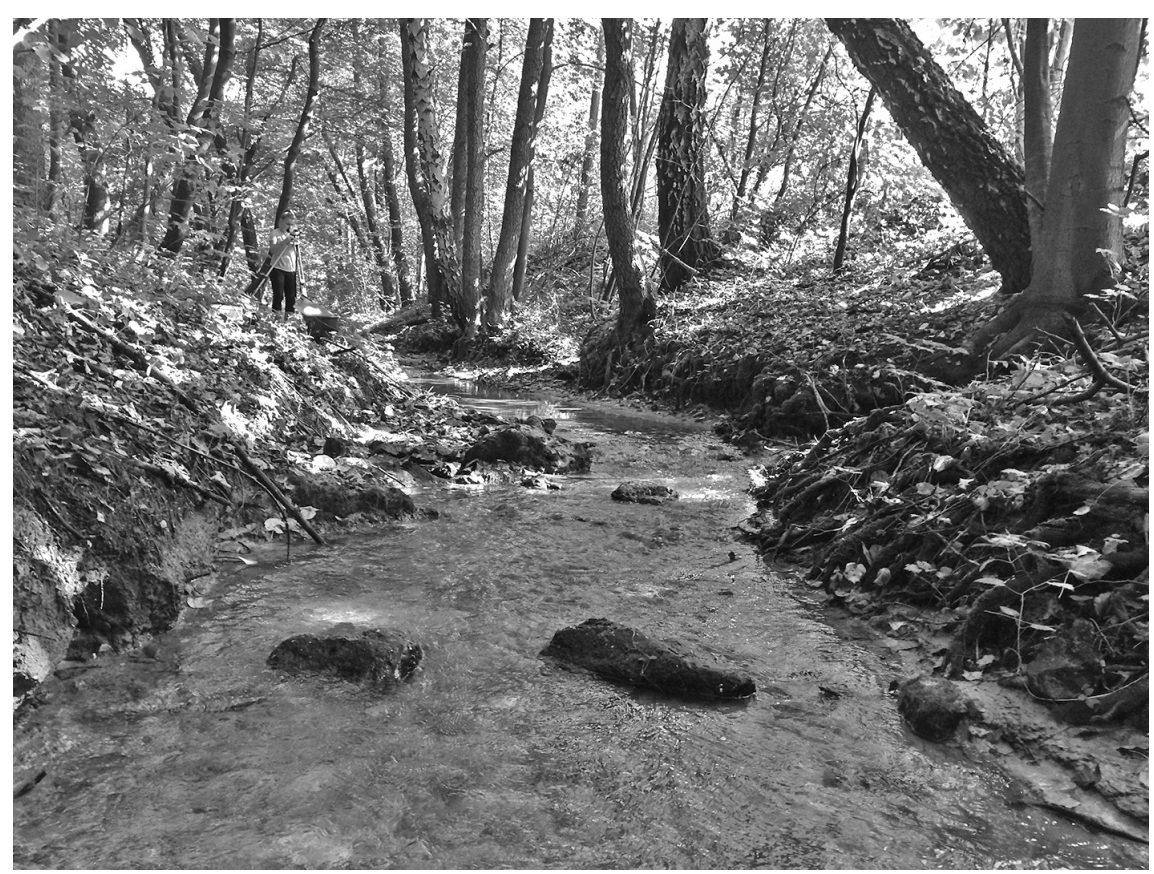

Fig. 3. Measuring section of the Będkówka stream - view on large roughness elements A and B in section II-II and large roughness element $\mathrm{C}$ in section $\mathrm{V}-\mathrm{V}$

Water flow velocities were measured in designated hydrometric verticals in each of nine cross-sections. Hydrometric measurements were carried out with the OTT Hydrometrie Nautilus C2000 hydrometric inductive current meter in accordance with the measuring procedure of the Polish Institute of Meteorology and Water Management (2002). On the grounds of the hydrometric measurements of the water flow velocity, the flow rate was calculated with Harlacher's method (Byczkowski, 1996). During hydrometric measurements also the Będkówka stream water temperature was measured. In the first measurement series it was $16{ }^{\circ} \mathrm{C}$, and in the second one it was $12{ }^{\circ} \mathrm{C}$. These temperatures were used to define the values of kinematic viscosity coefficient of water, which is essential to calculate the Reynolds number.

Dimensionless resistance coefficient $(\lambda)$ was calculated from the Colebrook-White equation. According to Żbikowski (1995), the Colebrook-White equation for a uniform flow in closed channels should not be used for open bed sections as it does not take two factors into account: bed's cross-section form variability and roughness changes along the diameter of wetted perimeter. Schroeder (1989) claims, however, that if the Reynolds number values are lower than 25.000, the equation may be used to calculate the resistance coefficient in the bed with the following formula:

$$
\frac{1}{\sqrt{\lambda}}=-2 \log \left[\frac{2.51}{R_{e} \cdot \sqrt{\lambda}}+\frac{k_{s}}{14.84 \cdot R_{h}}\right]
$$

where:

$$
\begin{aligned}
& R_{e}-\text { Reynolds number for water flow }[-], \\
& v-\text { kinematic viscosity coefficient }\left[\mathrm{m}^{2} \cdot \mathrm{s}^{-1}\right], \\
& k_{s}-\text { absolute roughness }[\mathrm{m}], \\
& R_{h}-\text { hydraulic radius }[\mathrm{m}], \\
& \lambda-\text { dimensionless resistance coefficient }[-] .
\end{aligned}
$$

In the above formula (1), which is a recursive equation, the dimensionless resistance coefficient was calculated with an iterative method. When the Reynolds number in the coefficient for hydraulic conditions was higher than 25.000, a simplified form of the equation was used:

$$
\lambda=\left[-2 \log \left(\frac{k_{s}}{14.84 \cdot R_{h}}\right)\right]^{-2}
$$

parameters as in the formula (1). 
In the above formulas, the overall roughness was determined as the absolute bed roughness according to Nikuradse (van Rijn, 1984). It can be determined with formulas given by Kamphius, Hey, Mahmood, Gładki, Ackers and White, Strickler (Yen 2002), among others. The absolute bed roughness was determined with Gładki's formula $(1974,1979)$ that was developed on the grounds of studies on Carpathian tributaries of Vistula:

$$
k_{s}=2.3 \cdot d_{80}
$$

where:

$d_{80}$ - grain diameter which along with finer elements constitutes $80 \%$ of the sample's weight.

$\mathrm{d}_{80}$ diameter was defined from a size distribution curve developed on the bottom sediments of an analysis obtained from the research section.

For every cross-section a roughness coefficient was calculated, which is dependent on the dimensionless resistance coefficient and a hydraulic radius. The hydraulic radius was defined as a quotient of the cross-sectional surface area and the length of the wetted perimeter. Roughness coefficient was defined from the following formula:

$$
n=R_{h}^{\frac{1}{6}} \sqrt{\frac{\lambda}{8 g}}
$$

where:

$\mathrm{g}$ - gravitational acceleration $\left[\mathrm{m} \cdot \mathrm{s}^{-2}\right]$, and other parameters as in the formula (1).

In case of the water flow appearing around large roughness elements, the roughness coefficients for sections, where these elements had been present, were calculated for respective parts of stream bed sections. These parts were created based on the position of the element - one element divides the flow in section into two parts, and two elements divide the bed into three parts. Assuming that the total bed flow rate is equal to the sum of flows in particular constituent surfaces, the mean roughness coefficient $\left(n_{\mathrm{sr}}\right)$ was calculated with Lotter's formula (1933):

$$
n_{s r}=\frac{O R_{h}^{\frac{5}{3}}}{\sum \frac{O_{i} R_{h i}^{\frac{5}{3}}}{n_{i}}}
$$

where parameters are as in formula (4), whereby: $O-$ wetted perimeter of the whole section [m], $O_{i}-$ wetted perimeter of ith part of the section [m], $n_{i}-$ roughness coefficient of ith part of the section $\left[\mathrm{m}^{-1 / 3} \cdot \mathrm{s}\right]$.

\section{RESULTS}

As a result of geodetic measurements, the mean bottom slope in the studied section was determined, and it equals $2.2 \%$. Also, local bottom slopes were determined in sections above and below each section, where elements were present, in distances of 1.2$-2.2 \mathrm{~m}$ and $0.5-0.9 \mathrm{~m}$ respectively. Local slopes determined for sections with elements are $1.23 \%$ (section II), 3.37\% (section V) and 1.05\% (section VIII). Water table width in sections I-VIII equalled 1.3-2.2 m. Dimensions of four large roughness elements can be found in Table 1. Mean element diameter in studied sections, which was determined based on parameters found in Table 1, is $0.15 \mathrm{~m}$, whereas the largest diameters of elements obtained from the river load did not exceed $0.08 \mathrm{~m}$. According to PN-EN ISO 146882:2006, a stream bottom is composed of: coarse gravel with $18.63 \%$ of stone fraction, $76.63 \%$ of stone fraction, $4.13 \%$ of sand fraction and $0.56 \%$ of dusty-argillaceous fraction. Determined element diameter $d_{80}$ is $39 \mathrm{~mm}$, and the calculated absolute bottom roughness according to Gładki's formula (3) is $0.091 \mathrm{~m}$.

Table 1. Parameters of large roughness elements in the Będkówka stream

\begin{tabular}{cccc}
\hline \multicolumn{4}{c}{ Size of large roughness elements [m] } \\
\hline Cross-section / element & Width & Length & Height \\
\hline II / A & 0.13 & 0.20 & 0.14 \\
\hline II / B & 0.16 & 0.20 & 0.12 \\
\hline V / C & 0.17 & 0.19 & 0.10 \\
\hline VIII / D & 0.13 & 0.10 & 0.15 \\
\hline
\end{tabular}

Total bed flow rate in the Będkówka stream was calculated based on the results of hydrometric measurements of water flow and it totalled $0.021 \mathrm{~m}^{3} \cdot \mathrm{s}^{-1}$ in the first series of measurements, and $0.040 \mathrm{~m}^{3} \cdot \mathrm{s}^{-1}$ 
in the second series of measurements. In the first series of measurements not all large roughness elements had been submerged, whereas in the second series they had. Water temperature was $16^{\circ} \mathrm{C}$ and $12{ }^{\circ} \mathrm{C}$ in the first and in the second series of measurements respectively. Calculated hydraulic parameters for measurement data from the first and the second series, including dimensionless resistance coefficients and the roughness coefficients, can be found in Table 2 and 3 respectively. Due to the fact that the large roughness elements were not submerged during the first series of measurements, the calculations for these elements' sections were performed in the same manner as for separate beds. In case of section II, the right $(\mathrm{P})$, middle (S) and left (L) parts were designated as separate sections from the right bank to element $\mathrm{A}$, from element $\mathrm{A}$ to element $\mathrm{B}$, and from element $\mathrm{B}$ to the left bank. In sections V and VII only the right $(\mathrm{P})$ and left $(\mathrm{L})$ parts were designated for single elements in these sections.

In tables 2 and 3 lines with parameters in bold relate to sections with large roughness elements. In these sections, the values of water flow velocity, resistance coefficients and roughness coefficients are higher than in other cross-sections.
Values of these hydraulic parameters with submerged large roughness elements (see: Table 3 ) turned out to be higher by $5.5 \%$ in section II than in section III located before it; by $7.7 \%$ in section $\mathrm{V}$ than in section VI located before it; and by $9.1 \%$ in section VIII than in section XI located before it. To perform such a comparison of conditions when large roughness elements are not submerged it is necessary to define mean roughness coefficient for sections where these elements are presents, where roughness coefficients were calculated for designated parts of the bed (sections marked: $\mathrm{P}, \mathrm{S}$ and L in Table 2). Mean roughness coefficient calculated with Lotter's formula (1933) in Table 4 is $0.043 \mathrm{~m}^{-1 / 3} \cdot \mathrm{s}$ for section II, $0.040 \mathrm{~m}^{-1 / 3} \cdot \mathrm{s}$ for section $\mathrm{V}$ and $0.035 \mathrm{~m}^{-1 / 3} \cdot \mathrm{s}$ for section VIII. These values are higher than roughness coefficient values for the stream's bed sections which were located before these sections by $20.8 \%$ in section II, $22.3 \%$ in section V, and just $2.4 \%$ in section VIII. Only in case of section VIII the value of sectional roughness coefficient with non-submerged large roughness element turned out to be slightly higher than in the section before it. What is more, when the element had been submerged, resistance and roughness coefficients turned out to be much higher in this section in compar-

Table 2. Hydraulic parameters obtained from measurements in the first series

\begin{tabular}{ccccccc}
\hline Cross-section & $\begin{array}{c}\text { Maximal water } \\
\text { depth } \\
h[\mathrm{~m}]\end{array}$ & $\begin{array}{c}\text { Mean flow } \\
\text { velocity } \\
V_{s}\left[\mathrm{~m} \cdot \mathrm{s}^{-1}\right]\end{array}$ & $\begin{array}{c}\text { Cross-section } \\
\text { area } \\
F\left[\mathrm{~m}^{2}\right]\end{array}$ & $\begin{array}{c}\text { Reynolds } \\
\text { number } \\
R_{e}\end{array}$ & $\begin{array}{c}\text { Dimensionless } \\
\text { resistance } \\
\text { coefficient } \\
\lambda[-]\end{array}$ & $\begin{array}{c}\text { Roughness } \\
\text { coefficient } \\
{\left[\mathrm{m}^{-1 / 3} \cdot \mathrm{s}\right]}\end{array}$ \\
\hline I & 0.11 & 0.141 & 0.152 & 10235 & 0.200 & 0.033 \\
\hline II (P) & $\mathbf{0 . 1 0}$ & $\mathbf{1 . 1 2 8}$ & $\mathbf{0 . 0 1 9}$ & $\mathbf{4 8 1 0 3}$ & $\mathbf{0 . 3 6 6}$ & $\mathbf{0 . 0 4 1}$ \\
\hline II (S) & $\mathbf{0 . 1 0}$ & $\mathbf{1 . 1 2 0}$ & $\mathbf{0 . 0 1 9}$ & $\mathbf{5 0 5 0 2}$ & $\mathbf{0 . 3 4 6}$ & $\mathbf{0 . 0 4 0}$ \\
\hline II (L) & $\mathbf{0 . 1 0}$ & $\mathbf{1 . 1 7 5}$ & $\mathbf{0 . 0 1 8}$ & $\mathbf{3 7 7 2 8}$ & $\mathbf{0 . 5 0 6}$ & $\mathbf{0 . 0 4 6}$ \\
\hline III & 0.10 & 0.189 & 0.113 & 10514 & 0.250 & 0.036 \\
\hline IV & 0.10 & 0.083 & 0.258 & 14577 & 0.120 & 0.029 \\
\hline V (P) & $\mathbf{0 . 0 7}$ & $\mathbf{0 . 5 4 4}$ & $\mathbf{0 . 0 3 9}$ & $\mathbf{2 0 4 6 9}$ & $\mathbf{0 . 3 6 0}$ & $\mathbf{0 . 0 4 0}$ \\
\hline V (L) & $\mathbf{0 . 0 7}$ & $\mathbf{0 . 9 9 5}$ & $\mathbf{0 . 0 2 2}$ & $\mathbf{4 1 8 2 9}$ & $\mathbf{0 . 3 7 2}$ & $\mathbf{0 . 0 4 1}$ \\
\hline VI & 0.12 & 0.225 & 0.095 & 17334 & 0.191 & 0.033 \\
\hline VII & 0.08 & 0.236 & 0.091 & 13179 & 0.250 & 0.036 \\
\hline VIII (P) & $\mathbf{0 . 1 2}$ & $\mathbf{0 . 3 8 9}$ & $\mathbf{0 . 0 5 5}$ & $\mathbf{2 9 6 0 2}$ & $\mathbf{0 . 2 1 5}$ & $\mathbf{0 . 0 3 5}$ \\
\hline VIII (L) & $\mathbf{0 . 1 2}$ & $\mathbf{0 . 3 5 1}$ & $\mathbf{0 . 0 6 1}$ & $\mathbf{2 2 1 1 6}$ & $\mathbf{0 . 2 2 4}$ & $\mathbf{0 . 0 3 5}$ \\
\hline IX & 0.11 & 0.153 & 0.140 & 10871 & 0.212 & 0.034 \\
\hline
\end{tabular}


Michalec, B., Zwolenik, M. (2019). Assessment of the influence of large roughness elements on hydraulic conditions of water flow in the Będkówka stream channel. Acta Sci. Pol., Formatio Circumiectus, 18 (2), 13-22. DOI: http://dx.doi.org/10.15576/ASP.FC/2019.18.2.13

Table 3. Hydraulic parameters obtained from measurements in the second series

\begin{tabular}{ccccccc}
\hline Cross-section & $\begin{array}{c}\text { Maximal water } \\
\text { depth } \\
h[\mathrm{~m}]\end{array}$ & $\begin{array}{c}\text { Mean flow } \\
\text { velocity } \\
V_{s}\left[\mathrm{~m}^{-1} \mathrm{~s}^{-1}\right.\end{array}$ & $\begin{array}{c}\text { Cross-section } \\
\text { area } \\
F\left[\mathrm{~m}^{2}\right]\end{array}$ & $\begin{array}{c}\text { Reynolds } \\
\text { number } \\
R_{e}\end{array}$ & $\begin{array}{c}\text { Dimensionless } \\
\text { resistance } \\
\text { coefficient } \\
\lambda[-]\end{array}$ & $\begin{array}{c}\text { Roughness } \\
\text { coefficient } \\
{\left[\mathrm{m}^{-1 / 3} \cdot \mathrm{s}\right]}\end{array}$ \\
\hline I & 0.21 & 0.154 & 0.260 & 16424 & 0.143 & 0.031 \\
\hline II & $\mathbf{0 . 1 8}$ & $\mathbf{0 . 2 2 6}$ & $\mathbf{0 . 1 7 7}$ & $\mathbf{1 5 3 7 0}$ & $\mathbf{0 . 2 1 2}$ & $\mathbf{0 . 0 3 4}$ \\
\hline III & 0.17 & 0.214 & 0.187 & 18443 & 0.176 & 0.032 \\
\hline IV & 0.09 & 0.351 & 0.114 & 23506 & 0.217 & 0.034 \\
\hline V & $\mathbf{0 . 1 3}$ & $\mathbf{0 . 3 5 4}$ & $\mathbf{0 . 1 1 3}$ & $\mathbf{1 8 4 4 3}$ & $\mathbf{0 . 2 6 3}$ & $\mathbf{0 . 0 3 6}$ \\
\hline VI & 0.16 & 0.350 & 0.114 & 32111 & 0.170 & 0.033 \\
\hline VII & 0.15 & 0.187 & 0.214 & 16128 & 0.176 & 0.032 \\
\hline VIII & $\mathbf{0 . 1 9}$ & $\mathbf{0 . 2 1 9}$ & $\mathbf{0 . 1 8 3}$ & $\mathbf{1 2 4 5 6}$ & $\mathbf{0 . 1 8 4}$ & $\mathbf{0 . 0 3 4}$ \\
\hline IX & 0.16 & 0.219 & 0.183 & 20669 & 0.164 & 0.031 \\
\hline
\end{tabular}

ison to the section located before it, i.e. section IX. In these conditions the rise of roughness coefficient value was $9.1 \%$, as presented above.

In Table 4 also values for sectional roughness coefficients for sections with large roughness elements (sections III and VIII) were given, as calculated for these sections without elements. Also, cross-sectional areas with element $(\mathrm{F})$ and without element $\left(\mathrm{F}^{\prime}\right)$ were calculated, as well as element's area in sectional plane $\left(F_{z}\right)$, and on this ground the section cover coefficients $(\omega)$ were defined, as a quotient of $F_{z}$ and $F$ '.

Obtained calculation results of the sectional cover coefficients $(\omega)$ and the degree of change of rough- ness coefficient $\Delta \mathrm{n}$ are presented in Fig. 4. As each measurement series was performed in different water flow conditions (the first one without, and the second one with submerged large roughness elements), for every series a correlation curve was defined. Due to small amount of data in each series, only straight lines related to linear regression formulas were designated for each series, without providing values of correlation and determination coefficients. Performed pilot studies (completed with results from upcoming planned measurements) will enable the verification of correctness of taken linear regression formulas.

Table 4. Cross-sectional cover coefficient $(\omega)$ and degree of change of roughness coefficient $\Delta \mathrm{n}$

\begin{tabular}{|c|c|c|c|c|c|c|c|c|}
\hline \multirow[b]{2}{*}{$\begin{array}{l}\text { Measurement } \\
\text { series }\end{array}$} & \multirow[b]{2}{*}{ Cross-section } & \multirow[b]{2}{*}{$\mathrm{F}\left[\mathrm{m}^{2}\right]$} & \multirow[b]{2}{*}{$\mathrm{F}^{\prime}\left[\mathrm{m}^{2}\right]$} & \multirow[b]{2}{*}{$\mathrm{F}_{\mathrm{z}}\left[\mathrm{m}^{2}\right]$} & \multirow[b]{2}{*}{$\begin{array}{c}\text { Cross-sectional } \\
\text { cover coefficient } \\
\omega[-]\end{array}$} & \multicolumn{2}{|c|}{ Roughness coefficient } & \multirow[b]{2}{*}{$\begin{array}{c}\Delta \mathrm{n} \\
{[\%]}\end{array}$} \\
\hline & & & & & & $\begin{array}{c}\text { with element } \\
\mathrm{n} \\
{\left[\mathrm{m}^{-1 / 3} \cdot \mathrm{s}\right]}\end{array}$ & $\begin{array}{c}\text { without } \\
\text { element } \\
\mathrm{n}_{\mathrm{Z}} \\
{\left[\mathrm{m}^{-1 / 3} \cdot \mathrm{s}\right]}\end{array}$ & \\
\hline \multirow{3}{*}{$1 \mathrm{st}$} & II & 0.056 & 0.119 & 0.063 & 0.527 & 0.043 & 0.035 & 23.4 \\
\hline & $\mathrm{V}$ & 0.061 & 0.079 & 0.018 & 0.227 & 0.040 & 0.038 & 6.0 \\
\hline & VIII & 0.116 & 0.161 & 0.045 & 0.281 & 0.035 & 0.032 & 7.8 \\
\hline \multirow{3}{*}{2 nd } & II & 0.177 & 0.259 & 0.082 & 0.316 & 0.034 & 0.030 & 11.7 \\
\hline & $\mathrm{V}$ & 0.113 & 0.138 & 0.025 & 0.181 & 0.036 & 0.035 & 4.4 \\
\hline & VIII & 0.183 & 0.248 & 0.065 & 0.262 & 0.034 & 0.032 & 7.1 \\
\hline
\end{tabular}

Where: $\mathrm{F}$ - cross-sectional area with element, $\mathrm{F}^{\prime}$ - cross-sectional area without element, $\mathrm{F}_{\mathrm{z}}$ - element area in cross-sectional plane 


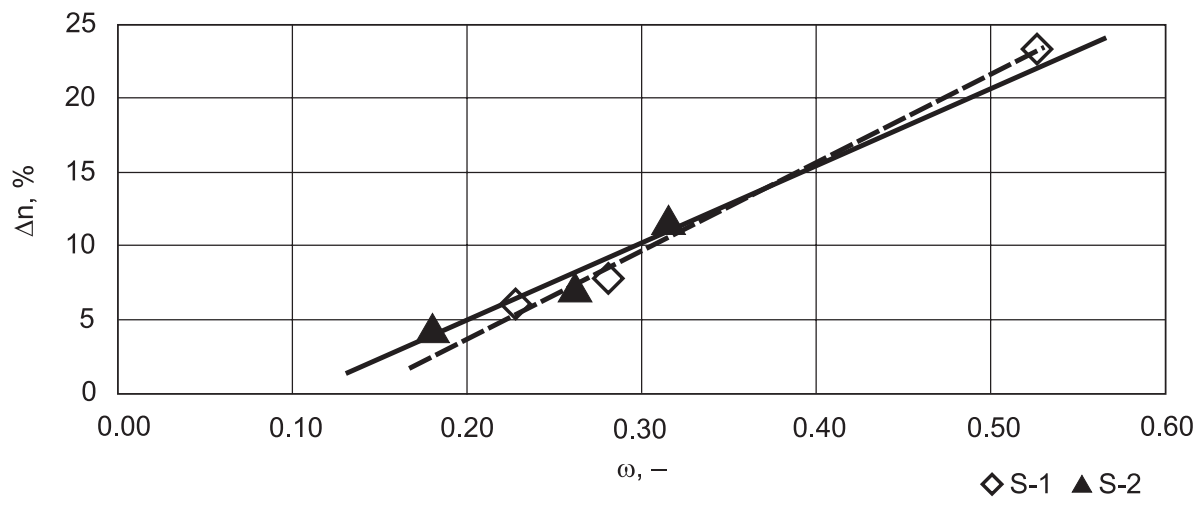

Fig. 4. Regression relationships of the degree of change of roughness coefficient $(\Delta \mathrm{n})$ and of the cross-sectional cover coefficient $(\omega)$

\section{SUMMARY}

In the study, the Colebrook-White formula was used in order to determine the Będkówka stream sectional resistance coefficient with large roughness element, despite Falvey's remarks (1987), who claims that factors like wavy motion of water or bridge supports in the bed, which are not taken into account in the formula, should be considered separately. Knight et al. (2018) suggest that using the Colebrook-White equation may provide unrealistically high resistances coefficient if the $\mathrm{k}_{\mathrm{s}}$ to bed filling ratio is high, e.g. in a natural channel, where roughness size may be comparable to depth like in the case of rocks. As a result of the performed studies it turned out that obtained values of the sectional resistance coefficient with large roughness element had not been unrealistic - for section II they had risen by $50.4 \%$ and $47.6 \%$ for the first and the second measurement series respectively; for section $\mathrm{V}$ they had risen by $20.6 \%$ and $14.8 \%$ for the first and the second measurement series respectively; for section VIII they had risen by $15.0 \%$ and $29.1 \%$ for the first and the second measurement series respectively.

What is more, the use of the Colebrook-White equation to calculate the resistance coefficient in stream beds is limited because of the condition related to the flow depth to roughness height ratio. This ratio may not be lower than ca. 10:1 (Falvey 1987). The condition was met as the determined roughness was higher than $0.09 \mathrm{~mm}$, and the maximal sectional filling in the Będkówka stream during measurements did not exceed $0.2 \mathrm{~m}$.

Regression lines presented in Fig. 4 are nearly parallel, despite the fact that they had been calculated for data obtained in two different hydraulic conditions - the water flow appearing around elements (series 1) and the element submersion (series 2). Element submersion with 3-6 cm layer corresponds to transitional conditions, what constitutes $26-50 \%$ of grain height, and value range of sectional cover degree $(\omega)$ of $0.18-0.32$ corresponds to the degree of change of roughness coefficient $(\Delta \mathrm{n})$ from $4.4 \%$ to $11.7 \%$. Values of degree of sectional cover coefficient with non-submerged elements correspond to the ranges of the degree of change of roughness coefficient, what may suggest possibility of formulating one dependency $\Delta n=f(\omega)$ for both conditions - with and without submerged large roughness element. As the results are considered to be preliminary, the authors plan to perform further measurement series at more diverse sectional water flow conditions with large roughness elements.

Data in Table 4 show that element's effect on the water flow conditions causes the rise of total resistances, what had been caused by the flow resistance around large roughness elements and resistances of surface friction of these elements. Friction resistances on smooth large roughness elements surfaces are significantly lower than resistances of flow around these elements. Therefore, resistances of flow around the elements influence the increase of roughness coefficient 
by $\Delta \mathrm{n}$ value, the so-called degree of change of roughness coefficient.

The development of the $\Delta \mathrm{n}=\mathrm{f}(\omega)$ dependence for diverse hydraulic conditions of water flow in the large roughness elements zone in the river bed will serve as a tool to determine the change of hydraulic conditions of water flow, expressed by the change of the roughness coefficient in the undertaken project works, under which it is planned to introduce large roughness elements into the river bed.

\section{REFERENCES}

Bacuła, A., Plesiński, K., Radecki-Pawlik, A. (2013). Warunki hydrodynamiczne oraz hydromorfologiczne w dwóch potokach gorczańskich Jaszcze i Jamne w Karpatach Polskich. Przegląd Naukowy - Inżynieria i Kształtowanie Środowiska, 61, 249-261.

Byczkowski, A. (1996). Hydrologia. Tom 2. Warszawa: Wydawnictwo SGGW.

Carson, M. A., Griffiths, G. A. (1987). Bedload transport in gravel channels. J. Hydrol., New Zealand, 26(1), 151.

Faley, H.T. (1987). Friction factor resistance in open and closed conduits. Technical Report: PAP-1156, Bureau of Reclamation, Washington.

FAO/DVWK. Fish passes - Design, dimensions and monitoring. Food and Agriculture Organization of the United Nations and Deutscher Verband für Wasserwirtschaft und Kulturbau e.V. Rome, 2002.

Gladki, H. (1979). Resistance to flow in alluvial channels with coarse bed materials. J. Hydraul. Res., 17, 2, 121-128 .

Gładki, H. (1976). Opory i prędkość przepływu w korytach rzek górskich na przykładzie karpackich dopływów Wisły. Zesz. Nauk. AR w Krakowie nr 118, seria: Rozprawy, 43, 142.

Gomez, B., Church, M. (1989). An assessment of bed-load sediment transport formulas for gravel bed rivers. Water Resour. Res., 25(6), 1161-1186.

Knight, D. W., Hazlewood, C., Lamb, R., Samuels, P.G., Shiono, K. (2018). Practical Channel Hydraulics. 2nd edition: Roughness, Conveyance and Afflux. CRC Press, Taylor and Francis Group.
Korpak, J., Krzemień, K., Radecki-Pawlik, A. (2008). Wpływ czynników antropogenicznych na zmiany koryt cieków karpackich. Infrastruktura i Ekologia Terenów Wiejskich 4, Monografia. Kraków: PAN.

Lotter, G. K. (1933). Considerations on Hydraulic design of channel with different roughness of walls. Transactions of All-Union Scientific Research Institution of Hydraulic Engineering 9, 238-242.

Michalec, B., Strutyński, M. (2010). Definition of dimensionless coefficient of resistance and coefficient of roughness in cross-section of stream with large roughness element. Infrastruktura i Ekologia Terenów Wiejskich, 11, 15-22.

Millar, R. G. (1999). Grain and form resistance in gravel-bed rivers. J. Hydraul. Res., 37(3), 303-312.

Millar, R. G., Quick, M. C. (1994). Flow resistance of high-gradient gravel channels. Hydraulic Engineering '94, edited by G. V. Cotroneo and R. R. Rumer, 717-721, ASCE, New York.

Nitsche, M., Rickenmann, D., Turowski, J. M., Badoux, A., Kirchner, J. W. (2011). Evaluation of bedload transport predictions using flow resistance equations to account for macro-roughness in steep mountain streams. Water Resources Research, 47, W08513, 21 pp.

PN-EN ISO 14688-2:2006. Badania geotechniczne, oznaczanie i klasyfikowanie gruntów. Część 2: Zasady klasyfikowania. Warszawa: Polski Komitet Normalizacyjny, 2012.

Procedura pomiarowa. Pomiar natężenia przepływu za pomocą młynka hydrometrycznego - wykonany w bród. IMGW/PSHM/SPO/POM/2002, maszynopis.

Radecki-Pawlik, A. (2014). Hydromorfologia rzek i potoków górskich - działy wybrane. Kraków: Wydawnictwo UR, 306.

Strużyński, A., Bartnik, W., Kulesza, K., Czoch, K. (2013). Równowaga hydrodynamiczna ważnym parametrem kształtującym stan ekologiczny cieków karpackich. Rocznik Ochrona Środowiska, 15, 2591-2610.

van Rijn, L. C. (1984). Sediment transport. Part II: Suspended load transport. Journal of Hydraulic Engineering, $110,10,1613-1641$.

Yen, B. C. (2002). Open Channel Flow Resistance. J. Hydraul. Eng., 128/1, 20-39. 


\section{OKREŚLENIE WPŁYWU ZIAREN PONADWYMIAROWYCH NA WARUNKI HYDRAULICZNE PRZEPEYWU WODY W KORYCIE POTOKU BĘDKÓWKA}

\section{ABSTRAKT}

\section{Cel pracy}

W pracy przedstawiono wyniki badań przeprowadzonych w potoku Będkówka, których celem było określenie wpływu ziaren ponadwymiarowych na zmianę wartości współczynników szorstkości oraz współczynników oporów.

\section{Materiat i metody}

Do badań wytypowano odcinek potoku, na którym wyznaczono dziewięć przekrojów pomiarowych, w tym $\mathrm{w}$ trzech z nich znajdowały się ziarna ponadwymiarowe. Bezwymiarowy współczynnik oporów $(\lambda)$ został obliczony z równania Colebrooka-White’a.

\section{Wyniki i wnioski}

Stwierdzono, że w przekrojach z ziarnami ponadwymiarowymi zarówno prędkości przepływu wody, jak również współczynniki oporu i szorstkości, uzyskują wartości większe niż w pozostałych przekrojach poprzecznych. Obliczono również współczynnik przesłonięcia przekroju ( $\omega)$ i stopień zmiany współczynnika szorstkości $\Delta \mathrm{n}$ i opracowano zależność regresyjną $\Delta \mathrm{n}=\mathrm{f}(\omega)$, określenia zmiany warunków hydraulicznych przepływu wody, wyrażonej za pomocą zmiany współczynnika szorstkości.

Słowa kluczowe: ziarno ponadwymiarowe, bezwymiarowy współczynnik oporów, współczynnik szorstkości 